DIGITAL COMMONS
@ UNIVERSITY OF SOUTH FLORIDA

Peace Studies

Volume 1

Issue 2 Genocide: Critical Issues

Article 6

September 2009

\title{
The Responsibility to Protect and Preventing Genocide in the Twenty-First Century
}

Herbert Hirsch

Follow this and additional works at: https://digitalcommons.usf.edu/jacaps

\section{Recommended Citation}

Hirsch, Herbert (2009) "The Responsibility to Protect and Preventing Genocide in the Twenty-First Century," Journal of African Conflicts and Peace Studies: Vol. 1: Iss. 2, 68-81.

DOI: http://dx.doi.org/10.5038/2325-484X.1.2.4

Available at: https://digitalcommons.usf.edu/jacaps/vol1/iss2/6

This Article is brought to you for free and open access by the Open Access Journals at Digital Commons @ University of South Florida. It has been accepted for inclusion in Journal of African Conflicts and Peace Studies by an authorized editor of Digital Commons @ University of South Florida. For more information, please contact digitalcommons@usf.edu. 


\author{
Journal of African Conflicts and Peace Studies
}

\title{
THE RESPONSIBILITY TO PROTECT AND PREVENTING GENOCIDE IN THE TWENTY FIRST CENTURY
}

\section{Herbert HIRSCH}

\begin{abstract}
As the new century rolls or: as genocide continues in places such as Dartui and the oic slogans such as "never again" and others retain the ring of insincerity. new prescriptions emerged as to how genocide is to be prevented in this 21 st century. Already. however the century is not so new and neither are the prescriptions. in order to fully understand the newesi of the new adeas The Responsibility to Protect. it must be placed within the context of international politıcs and a brief nisiory of prevention in the late Twentieth Century.
\end{abstract}

\section{Failure to Prevent Genocide in the Twentieth Century}

In order to understand the various means which have been proposed to prevent: genocide we must begin with a brief on the international state system. As elementary as this must appear: it is absolutely essential.

Beginning with the Peace of Westphalia in 1648, the nation state system grew and evolved in such a fashion that the resulting states have been guided in their behavior by two broad concepts: sovereignty and national interest. As much as we would like to believe that this has somehow been altered and thus changed over the years, the simple but profound fact is that international politics has been dominated by the international system of nation states and that remains true to this day. Tellingly, many present day conflicts involve not only failed or failing states but a desire on the part of some entity to establish a state of their own based on their ethnic, religious and/or some other identity.

This became particularly important at the end of the Cold War in the late 1990s when the world was confronted by a change in the dominant paradigm of international politics. From 1945 until through the end of the Cold War, international politics had been dominated by the bi-polar balance of power and the contest for dominance between the United States and the Former Soviet Union. When the Soviet Union suddenly collapsed, and along with it the former colonies of Eastern Europe, the world was cast into a much more complicated situation. Instead of two dominant super powers checking and balancing each other and fighting proxy wars but avoiding, or at least attempting to avoid, direct confrontation due to the fear of possible escalation to all out nuclear destruction, the world now was, in one sense, cast adrift. 


\section{Journal of African Conflicts and Peace Studies}

All the former colonies previously held together by threat or force of Soviet intervention suddenly wanted to invoke their sovereignty and to create a new ethnic or religiousbased (or other type) of nation state. In many cases this led to massive violations of human rights and genocide. As the 20th Century drew to a close, therefore, various cases of genocide, in particular in Rwanda and the former Yugoslavia, brought about renewed interest in how genocide might be prevented. Scholars and diplomats began to turn out books and articles, to have conferences and discussions on this topic, and to form organizations such as the International Association of Genocide Scholars. Some of the proposals included such ideas as the following:

1. Creation of a Genocide Early Warning System which would alert the public and exert pressure on nations or groups to stop atrocities. It would consider the indicators of genocide as identified by numerous scholars.

2. Creation of a UN Rapid Reaction Force.

3. Creation of ad hoc judicial tribunals. Special tribunals have limited jurisdiction and do not have the power to try crimes committed anywhere but in their area of jurisdiction. At first there were two tribunals: The International Criminal Tribunal for the former Yugoslavia (ICTY), created in May, 1993 and The International Criminal Tribunal for Rwanda (ICTR), created in 1994.

In addition, The United Nations also created Special Courts for East Timor, Sierra Leone, and Cambodia, and there have also been trials in Iraq. Some authorities regard the latter as of questionable legitimacy. The problem, of course, was that ad hoc tribunals did not provide a permanent mechanism to deal with genocide or human rights violations and so on July 1, 2002, the International Criminal Court (ICC) was created when the Rome Statute entered into force after being ratified by 60 states.

Other positive signs in regard to efforts aimed at prevention included the creation of International Criminal Tribunal for Sierra Leone, the Indictments of Augusto Pinochet and Slobodan Milosevic, and the February 2001 conviction for rape and sexual enslavement of three former members of the Bosnian Serb armed force who were found guilty of crimes against humanity and violating the laws of war. The latter was noteworthy because it was the first time that sexual enslavement and rape were punished as crimes against humanity. Also, although lagging behind in implementation and action, the creation of a Criminal Tribunal to try Khmer Rouge leaders who engineered the Cambodian genocide in the 1970s is noteworthy. 


\section{Journal of African Conflicts and Peace Studies}

Two events, however, side-tracked such progress toward genocide prevention. First, the election of George Bush as President of the United States in the disputed election of 2000 and, second, the events that took place on September 11, 2001, which shifted the world's and the United States' focus from genocide to terrorism.

Still, in spite of the overwhelming attention addressed towards terrorism certain nations remained concerned about genocide. Consequently, in January, 2004, the Government of Sweden attempted to re-focus the nations of the world on preventing genocide by convening the Fourth International Stockholm Forum on the Prevention of Genocide. Subsequently, on April 7, 2004, then UN Secretary General Kofi Annan announced he would appoint a Special Advisor on Genocide and start an action plan to prevent genocide. Specifically, this plan involved five points:

1. Preventing armed conflict;

2. Protection of civilians in armed conflict;

3. Ending impunity through judicial action in both national and international courts;

4. Information gathering and early warning through a UN Special Advisor for genocide prevention (now appointed); and

5. Swift and decisive action along a continuum of steps, including possible military action (Prevent Genocide International, 2004, p. 1).

Then, in September 2005, the United Nations met to devise a way to reform itself so that it would be more vigorous in preventing genocide. The United States, however, blocked language that stated that countries have an "obligation" to prevent genocide and substituted the following words in their place: "We are prepared to take collective action ... on a case by case basis."

Ultimately, what occurred during the late 1990s and the early part of the Twenty First Century was that humanitarianism became politicized. In fact, Foley (2008) argues that human rights and humanitarianism had became powerful political movements and represented what he refers to as a change to values politics as the number of NGOs grew rapidly. Malcomsen (2008), in a review of Foley, notes that such a situation led to increasing frustration since the very humanitarian values represented by this growth did not appear to be implemented in many parts of the world such as the Balkans, Central Africa, Sudan, and in other large portions of the world. 


\section{Journal of African Conflicts and Peace Studies}

The most preferred mechanism to achieve humanitarian goals became the International Criminal Court. Politics, however, in particular armed intervention under the rubric of humanitarian intervention, also was increasingly referred to as a solution and lead to what Foley (2008) refers to as "the integration of humanitarian assistance into military interventions" (p. 2). This has led, he contends, to unintended consequences including an increasing number of attacks on humanitarian aid workers. $\mathrm{He}$ adds that this led to the unfortunate tendency for those violating human rights to abandon the idea that aid workers are theoretically independent and neutral. When such individuals and groups are viewed as part of an armed intervention, or even a potential armed intervention, their neutrality is virtually abandoned and thus they come to be perceived as simply another instrument of a conquering and occupying armed force violating the sovereignty of the perpetrators of the violations and, thus, in their view, a legitimate target. This is where the idea of the Responsibility to Protect enters the fray.

\section{The Responsibility to Protect}

The attempt to find a method to get around sovereignty, which had stymied interventions in Bosnia and Rwanda, was further highlighted by the situation in Kosovo in 1999. The divided UN Security Council appeared to be prepared to stop any attempt to stop the advancing ethnic cleansing pursued by the forces of Serbia and, in desperation, then UN Secretary General Kofi Annan "made compelling pleas to the international community to try to find, once and for all, a new consensus on how to approach these issues to 'forge unity' around the basic questions of principle and process involved" (International Commission on Intervention and State Sovereignty, 2001, p. vii). According to the introduction to R2P, Annan posed the question as follows: ". . . if humanitarian intervention is, indeed, an unacceptable assault on sovereignty, how should we respond to Rwanda, to a Srebrenica -- to gross and systematic violations of human rights that affect every precept of our common humanity?" (International Commission on Intervention and State Sovereignty, 2001, p. vii).

In response to Annan's challenge, the Canadian government, along with several major foundations, established in September 2000, the International Commission on Intervention and State Sovereignty which resulted in the now famous doctrine of the "responsibility to protect." As noted in the introduction, the basic idea of the Responsibility to Protect is that "sovereign states have a responsibility to protect their 


\section{Journal of African Conflicts and Peace Studies}

own citizens from avoidable catastrophe -- from mass murder and rape, from starvation -- but that when they are unwilling or able to do so, that responsibility must be borne by the broader community of states" (International Commission on Intervention and State Sovereignty, 2001, p. VIII).

\section{The report proceeds to note that "The responsibility to protect embraces three specific responsibilities":}

A. The responsibility to prevent: to address both the root causes and direct causes of internal conflict and other man-made crises putting populations at risk;

B. The responsibility to react: to respond to situations of compelling human need with appropriate measures, which may include coercive measures like sanctions and international prosecution, and, in extreme cases, military intervention; and,

C. The responsibility to rebuild: to provide, particularly after a military intervention, full assistance with recovery, reconstruction and reconciliation, addressing the causes of the harm the intervention was designed to halt or avert.

When such responsibility is not exercised, a number of options are potentially triggered. The basic idea is that "Prevention is the single most important dimension of the responsibility to Protect" ( $p . x i)$ and should "always be exhausted before intervention is contemplated. . " (p.xi). In its conclusion, the report makes a series of recommendations to the United Nations:

"8.28 The Commission recommends to the General Assembly:

That the General Assembly adopt a draft declaratory resolution embodying the basic principles of the responsibility to protect, and containing four basic elements:

[1] an affirmation of the idea of sovereignty as responsibility;

[2] an assertion of the threefold responsibility of the international community of states -- to prevent, to react and to rebuild -- when faced with human protection claims in states that are either unable or unwilling to discharge 


\section{Journal of African Conflicts and Peace Studies}

their responsibility to protect;

[3] a definition of the threshold (large scale loss of life or ethnic cleansing, actual or apprehended) which human protection claims must meet if they are to justify military intervention; and

[4] an articulation of the precautionary principles (right intention, last resort, proportional means and reasonable prospects) that must be observed when military force is used for human protection purposes.

\subsection{The Commission recommends to the Security Council:}

(1) That the members of the Security Council should consider and seek to reach agreement on a set of guidelines, embracing the "Principles for Military Intervention" summarized in the Synopsis, to govern their responses to claims for military intervention for human protection purposes;

(2) That the Permanent Five members of the Security Council should consider and seek to reach agreement not to apply their veto power, in matters where their vital state interests are not involved, to obstruct the passage of resolutions authorizing military intervention for human protection purposes for which there is otherwise majority support; and

\subsection{The Commission recommends to the Secretary-General:}

That the Secretary-General give consideration, and consult as appropriate, with the President of the Security Council and the President of the General Assembly, as to how the substance and action recommendations of this report can best be advanced in those two bodies, and by his own further action."

As sensible as all of this may sound, when all is said and done, the atternpt to implement the responsibility to protect has run into numerous obstacles. The basic idea that sovereignty may be overcome when nations fail to protect their citizens from atrocity remains, even to this day, controversial.

\section{Problems with R2P and Genocide Prevention}

There are, in fact, many problems with the entire concept of "responsibility to protect." If I have this correct, a simplified view of how prevention is now supposed to work is. 
Hirsch: The Responsibility to Protect and Preventing Genocidein the Twen

\section{Journal of African Conflicts and Peace Studies}

that a "genocide early warning system" triggers a warning; which, in turn, sets off policies outlined in the R2P. These may include, but are not limited to:

1. Sanctions;

2. Humanitarian intervention;

3. Apprehension, trials and punishment of perpetrators; and

4. Reconciliation and rebuilding of the destroyed society.

Ultimately, if none of this occurs, the reason is a "failure of will."

As with so many attempts to overcome sovereignty and to prevent genocide, there is nothing, in general, to argue with, but there are major problems in conceptualization and implementation. In particular, there are (1) major weaknesses in the conceptualization and operationalizing of early warning systems and R2P, (2) there are major problems with sanctions and humanitarian intervention and (3) the overall explanation for why nothing is done begs the question and misses the reality of domestic and international politics. In fact, these are my main criticisms of most of the literature, scholarly and prescriptive, in the area of genocide studies, namely that R2P does not provide operational definitions necessary or sufficient to allow for the implementation of the ideas put forth.

Of course, words may have a profound impact and language carries thought and may motivate action, but the lack of specificity and the absence of clear and realistic descriptions and explanations allows the level of generality to persist, and that results in inaction.

\section{R2P in the "Real" World}

That R2P has become the new "panacea" vis-à-vis the prevention of genocide is made clear by the attention it has received in recent conferences, and in continued attempts to invoke it to deal with present genocidal situations in places such as Darfur. While critiques of the failure to implement R2P have appeared throughout the period, they have yet to address the lacunae in R2P or correct its weaknesses.

For example, in February 2008, John Prendergast and Lisa Rogoff distributed a paper entitled "R2P, The ICC, and Stopping Atrocities in the Real World." Therein, Prendergast and Rogoff (2008) argue that the R2P doctrine is "real only on paper" 


\section{Journal of African Conflicts and Peace Studies}

because it has essentially failed in Darfur, Congo, and Uganda. Continuing, they assert that "R2P's and the ICC's potential for confronting real cases of genocide and crimes against humanity remains largely unfulfilled" (p. 1).

They then proceed to examine the three cases in terms of what they call the "3Ps of crisis response": Peacemaking, Protection, and Punishment. They conclude that in Uganda there has been no protection or peacekeeping, but there has been some attempt at punishment. Similarly, they note that in Congo and Darfur there have also been real problems. Their lament could not have been more timely, yet their recommendations for action and their account of why none of these is implemented reflects the same old bromides that simply reinforce my present criticisms. For example, they recommend multilateral action, with increased participation and leadership by the United States and they contend that "It is only with significantly increased political will -- generated by the growing anti-genocide movement -- that this doctrine can help create a world in which R2P is the standard and the United Nations instinctively turns to this doctrine whenever it faces even the possibility of genocide or mass atrocity crimes" (Prendergast and Rogoff. 2008,p. 5) And how is this implemented? Change brought about by the voters "demanding that R2P becomes more than just a wonderful intention or bumper sticker slogan." (Prendergast and Rogoff, 2008, p. 5).

While the conceptualization of R2P is relatively new, and some ideas are slowly seeping into international law and international and national politics, we do not have to trace the attempts over the years to know that utopian thoughts often are not translated into action. Of course, our reach should exceed our grasp, but we also want to be able to grasp and hold on to some result.

My view is that the model of R2P, the explanation for the lack of action, the failure of will, and the three magic bullets intended to prevent genocide and save lives -- early warning systems, humanitarian intervention, and trials and punishment -- are based on the traditional models of genocide derived from study of The Armenian Genocide and The Holocaust, and to a lesser extent on the massacres in the former Yugoslavia and the genocide in Rwanda, and that they may no longer be the most salient models in the present century. While the 1948 United Nations Convention on the Prevention and Punishment of the Crime of Genocide, which defines genocide in international law, is based upon these models, and fits very nicely with the atrocities of the last century, the new century has brought new (or, at least, altered) paradigms. 


\section{Journal of African Conflicts and Peace Studies}

Confronted with the re-awakening of ethnic, tribal and religious conflict used in the service of political ends, the world appears to be much more complex then the bimodal balance of power that dominated the fifty or so odd years from World War II to 1999, and present grievously difficult problems for those who wish to prevent the apparent rising tide of war crimes, crimes against humanity and genocide. So, today, we are once again witness to a shifting set of paradigms as our recent conceptualization of genocide may no longer provide an adequate description of the real world of international and national politics.

Yet, most of our attempts to prevent or stop genocide, including R2P, are based on these increasingly outdated examples. What is left out of the conceptualization of R2P -- and this is a major weakness -- is that the new paradigm of atrocity crimes in this new century appears to involve large states, such as the United States action in Iraq, Russia in Chechnya, or non state actors, sometimes supported by states, such as Darfur and the Congo. While the traditional definition remains valid for genocide as manifested in the last century, it does not really fit the newer examples which may not fit the traditional definition of genocide but are nevertheless the modern face of human rights violations.

R2P, if it is to be successful, must address these new types of atrocities and attempt to get to the root causes. It is, therefore, necessary to begin to think seriously about modifying the legal and moral paradigms and to bring the definition into congruence with twenty first century behavior. Here we might point to the necessity of adding a new category of international crimes that fall between genocide and human rights violations. This has been convincingly argued by David Scheffer (2006) in Genocide Studies and Prevention: An International Journal, where he called for a category of crime to be labeled "atrocity crimes". Unfortunately, space constraints preclude discussing the latter in any detail.

R2P is designed to protect against small states, or small non state affiliated groups, committing large crimes, but not against large states committing large crimes. If this is, in fact, true, R2P neglects a huge chunk of human rights violations. Here it is important to point out that I am not arguing that implementing R2P and successfully dealing with Darfur, Congo or other examples is not important; rather, I am arguing our conceptualization of R2P and genocide ignores a major problem that reflects and helps explain why we are not able to deal with these large crimes committed by large states. Of course, it is also true that the world has not been successful in dealing with large crimes committed by smaller states or groups. For now, however, imagine attempting to apply R2P to the United States, or, for that matter, Russia or China. 


\title{
Journal of African Conflicts and Peace Studies
}

Empirically, it is most likely true that, in the 20th and 21 centuries, as many innocents were killed by war crimes and crimes against humanity, if not genocide, committed by the US as have been killed by, for example in Darfur upon which the world is now focused. Just take the most obvious examples such as Vietnam, Guatemala, EI Salvador, Nicaragua, Chile, Argentina, Persian Gulf, Iraq. It is quite ironic that the war in Iraq and the atrocities in Darfur have been equal in longevity.

R2P makes little or no impact on this aspect of atrocities, and, in fact, the document recognizes its relative impotence in sections 4.41 and 4.42 when faced by violations by the large states (International Commission on Intervention and State Sovereignty, 2001, p. 37). It states, for example, that the

\begin{abstract}
...application of this precautionary principle would on purely utilitarian grounds be likely to preclude military action against any of the five permanent members of the Security Council even if all the other conditions for intervention described here were met.... The same is true of other major powers who are not permanent members of the Security Council. This raises again the question of double standards -- but the Commission's position here, as elsewhere, is simply this: the reality of interventions may not be able to be mounted in every case where there is justification for doing so,is no reason for them not to be mounted in any case (International Commission on Intervention and State Sovereignty, 2001, p. 37).
\end{abstract}

In spite of the attempted rationalization, it remains the case the R2P has not been successfully implemented in cases for which the authors have held out the highest of hopes, small states or non state actors committing large crimes. This is perhaps most obvious with the ongoing atrocities in Darfur. The explanation often provided for this failure of implementation is the "failure of will" on the part of the large powers or the international and national political institutions.

\section{Failure to Prevent: Lack of Political Will}

As a result of the widespread human rights atrocities of the last century a new field of academic endeavor was created. Loosely called "genocide studies," this new focus of inquiry produced a virtual explosion of scholarship on the causes, history, and prevention of genocide. Scholars from many disciplines, as well as activists, diplomats, and international lawyers, have all contributed to the explosion of research which helped bring the topic to greater public consciousness than ever before. As noted above, the genocides in Bosnia and Rwanda, and more recently the situation in Darfur, made explicit the relevance of this issue for the modern world. The unchecked 


\section{Journal of African Conflicts and Peace Studies}

violence in the Darfur region of the Sudan continued (and continues) to reveal the difficulty experienced by the international community in intervening to prevent genocides and similar kinds of human rights abuses.

Despite the apparent increase in attention and interest that genocide has elicited in recent years, modern states consistently appear unable or unwilling to prevent or effectively intervene to stop the loss of life. Rising to grasp the hope represented by the wide spread public attention and the publication of The Responsibility to Protect, this failure on the part of the international community to act has become an important focus for many interested scholars and activists as they rush to attempt to explain the ongoing failure of international politics. Many attribute the lack of action to a "failure of will" on the part of political leaders and governmental institutions. These arguments, however, as popular and as appealing as they may be, dramatically oversimplify the situation

In the conclusion to her prize winning book, "A Problem from Hell:" America and the Age of Genocide, Samantha Power (2002) lays out a plan to prevent genocide. Couching it in the context of United States foreign policy, she begins with the assertion that "What is most shocking is that U.S. policy makers did almost nothing to deter the crime [of genocide]." (p. 504). The United States, according to Power (2002), did "not give genocide the moral attention it warranted" (p. 504). Finally, she comes to what has become the widely circulated notion that genocide could be prevented if the political will to act had been present: "the real reason the United States did not do what it could and should have done to stop genocide was not a lack of knowledge or influence but a lack of will" (Power, 2002, p. 508). As we shall see, this is an idea propounded by not only Samantha Power, but others as well.

It is my contention, however, that this widespread belief about the failure of political will is a necessary but not a sufficient explanation for the absence of action to stop genocide. Whatever the interpretation, we must acknowledge that Power, in relying on the notion of the failure of political will, in fact begs the question. "Why is there an absence of 'will'?" The reality is as old as the nation state system and harkens back to $\mathrm{R} 2 \mathrm{P}$ and the attempt to overcome sovereignty.

Political will, if we define it as the motivation and determination to act, in other words, is a result of perceived needs and pressures in both national and international politics. It is not the other way around. On one level, of course, it is true that political will is necessary, but it is hardly sufficient. Put yet another way, arguments about political will tend to ignore the psychological, political, cultural and institutional reasons that make 


\section{Journal of African Conflicts and Peace Studies}

preventing genocide, war crimes or other forms of human violence very difficult. It appears as though genocide scholars and others who study genocide would like to hold tight to the hope that when a political leader tells us they will stop the killing they really and truly mean it and that when a peace treaty is signed, or a verbal agreement is reached, the violence and torture will stop if only there exists the "political will" to make it happen.

Or, alternatively, when the Secretary of State or President of the United States labels a situation as "genocide," that this simple declaration will lead to action on the part of the state that they serve. Unfortunately, good words or a worthy cause do not necessarily translate into meaningful action, and political leaders often allow other concerns to trump humanitarian ones. In fact, acknowledging that genocide is taking place may in fact be a political tactic to divert criticism of the real lack of action. Very often in United States national politics issuing a statement is confused for action (Hirsch, 2002).

Making R2P, or any action to save life, a real and meaningful alternative to politics as usual requires much more than political will -- although that is surely important. It requires an in-depth understanding of the national and international political systems and the pressures generated and responded to not only by leaders but the public as well. In short, any prescription such as R2P must begin with a forthright understanding of how politics work.

Both international and national politics are messy and often lack coherence. The attempt to inject coherence into a chaotic system may lead to confusion and to an inability to deal with the complexity of those systems. For example, take the warning of Joseph Nye (2007) in his book Understanding International Conflicts: "The bipolar world is over, but it is not going to be replaced by a unipolar world empire that the United States controls alone. The world is already economically multipolar, and there will be a diffusion of power as the information revolution progresses, interdependence increases, and transnational actors become more important. The new world will not be neat, and you will have to live with that" (p. 282). This includes not only genocide scholars but activists and others interested in preventing genocide. 
Hirsch: The Responsibility to Protect and Preventing Genocide in the Twen

\section{Journal of African Conflicts and Peace Studies}

\section{Conclusion}

Finally, R2P is another in a long line of well-meaning attempts to reform the United Nations and the International State System. From World Federalism through functionalism and regionalism and arguments about the "end of history," to modern views of the impact of "cyberfeudalism" and globalism, we have seen --- in both the long- and the short- run -- numerous prescriptions for reform falter as they run aground on the shoals of sovereignty and self-interest.

\section{REFERENCES}

Bass, Gary J. (2008). Freedom's Battle: The Origins of Humanitarian Intervention. New York: Alfred A. Knopf.

Evans, Gareth. (2008). The Responsibility to Protect: Ending Mass Atrocity Crimes Once and For All. Washington, D.C.: Brookings Institution Press.

Foley, Conor. (2008). The Thin Blue Line: How Humanitarianism Went to War. London: Verso.

Hirsch, Herbert (2002). Anti-Genocide: Building an American Movement to Prevent Genocide. Westport, CT: Praeger.

International Commission on Intervention and State Sovereignty (2001). The Responsibility to Protect: Report of the International Commission on Intervention and State Sovereignty. Ottowa, ON, Canada: The International Commission on Intervention and State Sovereignty.

Malcomson, Scott (2008). "When to Intervene." The New York Times. December 14, Accessed at: ttp://www.nytimes.com/2008/12/14/books/review/Malcomson-t.html

Nye, Joseph S., Jr. (2007). Understanding International Conflicts: An Introduction to Theory and History. New York: Pearson/Longman.

Power, Samantha (2002). "The Problem from Hell": America in the Age of Genocide. New York: Basic Books. 


\section{Journal of African Conflicts and Peace Studies}

Prendergast, John and Lisa Rogoff. (2008). "R2P, The ICC, and Stopping Atrocities in the Real World" ENOUGH Strategy Paper \#13. February. Accessed at: http://www.americanprogress.org/issues/2008/03/pdf/enough icc.pdf

Prevent Genocide International. (2004) "United Nations Documents on Genocide Prevention. Kofi Annan's April 7, 2004 Action Plan to Prevent Genocide and a new UN Special Advisor on Genocide Prevention." Washington, DC: Author.

Scheffer, David. 2006. "Genocide and Atrocity Crimes." Genocide Studies and Prevention: An International Journal, December 1(3): $229=250$. 